\title{
Mutu Bakteriologis Pindang Tongkol (Euthynnus affinis) yang Berasal dari Beberapa Pasar di Yogyakarta
}

\section{Bacteriological Quality of Salted Tuna Fish (Euthynnus affinis) from Severals Markets in Yogyakarta}

\section{Ekawati Purwijantiningsih* dan Exsyupransia Mursyanti}

Fakultas Biologi, Universitas Atma Jaya Yogyakarta. Email: e_purwiyanti@yahoo.com

*Penulis untuk korespondensi

\begin{abstract}
Food poisoning cases need to be examinated intensively. There have been five poisoning cases reported between 2003-2004 in Sleman area. Three of them were caused by contaminated tuna fish. The objective of this research was to determine bacteriological quality of salted tuna fish from several markets in Yogyakarta. Salted tuna fish sample were collected from five markets, namely Beringharjo, Condongcatur, Demangan, Kranggan and Sentul. In each market, four vendors were selected. Bacteriological test were done including total microbe cells utilizing PCA medium, Coliform test utilizing VRBA medium. Identification and isolation of Vibrio parahaemolyticus use pre-enrichment selective medium of Alkaline Petone Water and selective Chromogenic medium agar for Vibrio. Salmonella test utilizing Chromogenic agar continued by utilizing TSI and LIA medium. The result showed that bacteriological quality of salted tuna fish from markets in Yogyakarta did not fulfill the requirements based on SNI 01-2717-1992. It was shown that total microbial count were high, i.e. $2.4 \times 10^{5}-5.27 \times 10^{7} \mathrm{CFU} / \mathrm{g}$. Coliform count ranged from $\left\langle 2.5 \times 10^{1}\right.$ - $>$ $6.5 \times 10^{6} \mathrm{CFU} / \mathrm{g}$. From 20 samples that were brought to analyzed, $60 \%$ was positively presumed contaminated by $V$. parahaemolyticus and $50 \%$ was positively presumed contaminated by Salmonella.
\end{abstract}

Key words : pindang tongkol, bacteriological quality

Diterima : 18 Oktober 2005, disetujui : 17 Januari 2006

\section{Pendahuluan}

Beberapa waktu ini keracunan makanan sering terjadi karena mengkonsumsi makanan yang diolah dalam jumlah besar, seperti makanan yang disajikan dalam suatu pesta, makanan untuk karyawan di kantor atau pabrik dan makanan yang dibagi-bagikan untuk anak sekolah. Selama tahun 2003-2004 telah terjadi lima kasus keracunan makanan di Kabupaten Sleman. Tiga kasus keracunan disebabkan oleh keracunan ikan tongkol yang dimasak oleh jasa boga dan diperuntukkan bagi karyawan perusahaan (Anonim, 2004).
Ikan merupakan produk yang mudah sekali mengalami kebusukan. Hal tersebut disebabkan karena kandungan air dan protein yang tinggi pada ikan, serta adanya proses autolisis yakni proses penguraian jaringan yang berjalan dengan sendirinya setelah ikan mati. Selain proses autolisis pembusukan ikan terjadi karena adanya mikrobia (Moeljanto, 1992)

Berbagai cara pengolahan telah dilakukan untuk menanggulangi kebusukan yang mudah terjadi pada ikan. Pemindangan merupakan salah satu teknik pengolahan dan pengawetan ikan yang cukup populer di Indonesia. Hal tersebut disebabkan karena ikan pindang umumnya disukai dan diterima masyarakat mengingat cita rasanya yang 
spesifik (Suliantari dkk., 1994). Sebanyak $5.232 .109 \mathrm{~kg}$ ikan pindang telah dikonsumsi di Yogyakarta selama tahun 2000. Menurut Priyono dan Raharjo (2003), diperkirakan sebanyak 13 ton ikan pindang dipasarkan dan diproduksi di Yogyakarta setiap bulannya. Dalam produksi ikan pindang terdapat beberapa kendala di antaranya yang utama menyangkut mutu dan masa simpan produk (Saleh dan Heruwati, 1995).

Menurut Hadiwiyoto (1997), mikrobia yang banyak mencemari produk hasil perikanan adalah bakteri. Hasil perikanan segar dari laut banyak terkontaminasi bakteri-bakteri Pseudomonas, Flavobacterium, Achromobacter, Sarcia, Serratia, Bacillus, Corinebacterium dan Vibrio. Penelitian yang dilakukan oleh Peranginangin (1995) menunjukkan pada ikan pindang kembung, layang dan bandeng yang berasal dari Jakarta dijumpai total mikrobia sebesar $7,3 \times 10^{5} ; 8,2$ $\mathrm{x} 10^{5}$ dan $1,1 \times 10^{7}$ koloni/ g.

Sebagai langkah awal dalam mengupayakan keamanan pangan bagi konsumen, khususnya produk ikan pindang maka perlu dilakukan kajian mengenai mutu bakteriologis pindang tongkol kranjangan yang dijual di pasar Yogyakarta. Penelitian ini merupakan penelitian awal yang bertujuan untuk mengetahui mutu bakteriologis pindang tongkol kranjangan yang berasal dari beberapa pasar di Yogyakarta.

\section{Metode Penelitian}

Pengambilan sampel pindang tongkol kranjangan dilakukan di lima pasar di Yogyakarta yakni pasar Beringharjo, Condongcatur, Demangan, Kranggan dan Sentul. Pada setiap pasar dipilih empat orang pedagang. Uji mikrobiologis meliputi total mikrobia, uji coliform, Vibrio parahaemolyticus dan Salmonella (Fardiaz, 1989; Rahayu, 2003).

Uji total mikrobia menggunakan media Plate Count Agar (PCA), uji bakteri coliform menggunakan media padat Violet Red Bile Salt Agar (VRBA). Uji $V$. parahaemolyticus menggunakan media selektif Kromagenik Agar, sebelumnya sampel diperkaya dengan Alkaline Peptone Water (APW). Uji selanjutnya dengan menumbuhkan isolat yang diduga $V$. parahaemolyticus pada media Nutrien Cair yang ditambahkan dengan variasi konsentrasi NaCl. Uji Salmonella menggunakan media selektif Kromagenik Agar, sebelumnya sampel diresusitasi dengan laktosa cair dan dilakukan pengkayaan dengan Tetrathionat Broth Base (TBB), selanjutnya dilakukan uji pendugaan pada media Triple Sugar Iron (TSI) dan Lisin Iron Agar (LIA).

Sebagai data sekunder untuk memperkuat analisis dilakukan wawancara dengan pedagang mengenai asal pindang, umur simpan, kriteria pindang yang dijual dan sisa dagangan per hari, selain itu juga dilakukan pengamatan mengenai kondisi sekitar tempat penjualan.

\section{Hasil dan Pembahasan}

Berdasarkan hasil penelitian yang dilakukan pada sampel pindang tongkol kranjangan yang berasal dari 20 pedagang yang tersebar di 5 pasar di Yogyakarta, yaitu Beringharjo, Condongcatur, Demangan, Kranggan dan Sentul (diambil 4 pedagang dari setiap pasar) diperoleh hasil seperti terlihat pada Tabel 1. Berdasarkan hasil penelitian tersebut dapat diketahui bahwa mutu bakteriologis pindang tongkol kranjangan yang berasal dari berbagai pasar di Yogyakarta belum memenuhi persyaratan yang ditetapkan oleh SNI (1992). Hal tersebut ditunjukkan dengan jumlah mikrobia total yang cukup tinggi berkisar antara $2,4 \times 10^{5}-5,27 \times 10^{7}$ $\mathrm{CFU} / \mathrm{g}$. Kandungan coliform berkisar antara $<2,5 \times 10^{1}->6,5 \times 10^{6} \mathrm{CFU} / \mathrm{g}$, sedangkan hanya 1 sampel yang diduga tidak mengandung $V$. parahaemolyticus dan 4 sampel yang diduga tidak mengandung Salmonella. 
Tabel 1. Kandungan Bakteri pada Pindang Tongkol yang Berasal dari Beberapa Pasar di Yogyakarta

\begin{tabular}{|c|c|c|c|c|c|}
\hline \multicolumn{2}{|c|}{ Asal Sampel } & \multirow{2}{*}{$\begin{array}{l}\text { Total mikrobia } \\
\text { (CFU/g) }\end{array}$} & \multirow{2}{*}{$\begin{array}{c}\text { Coliform } \\
\text { (CFU/g) }\end{array}$} & \multirow[t]{2}{*}{ V.parahaemolyticus } & \multirow[t]{2}{*}{ Salmonella } \\
\hline Nama Pasar & Pedagang & & & & \\
\hline \multirow[t]{4}{*}{ Beringharjo } & 1 & $8,56.10^{6}$ & $1,77.10^{4}$ & + & + \\
\hline & 2 & $>6,5 \cdot 10^{6}$ & $6,39 \cdot 10^{4}$ & + & - \\
\hline & 3 & $>6,5 \cdot 10^{6}$ & $4,43.10^{6}$ & + & + \\
\hline & 4 & $6,16.10^{6}$ & $5,52.10^{6}$ & + & + \\
\hline \multirow[t]{4}{*}{ Condongcatur } & 1 & $>6,5 \cdot 10^{6}$ & $7,29.10^{5}$ & + & + \\
\hline & 2 & $3,52.10^{5}$ & $3,27.10^{4}$ & + & + \\
\hline & 3 & $2,94.10^{5}$ & $1,71.10^{4}$ & + & + \\
\hline & 4 & $>6,5 \cdot 10^{6}$ & $4,6.10^{4}$ & + & + \\
\hline \multirow[t]{4}{*}{ Demangan } & 1 & $2,4.10^{5}$ & 2120 & + & + \\
\hline & 2 & $2,85.10^{5}$ & 5500 & + & + \\
\hline & 3 & $2,36.10^{5}$ & $<2,5.10^{1}$ & + & + \\
\hline & 4 & $4,87.10^{6}$ & $2,96.10^{5}$ & + & + \\
\hline \multirow[t]{4}{*}{ Kranggan } & 1 & $2,52.10^{7}$ & $>6,5 \cdot 10^{5}$ & + & + \\
\hline & 2 & $5,24.10^{7}$ & $7,76.10^{5}$ & + & + \\
\hline & 3 & $5.10^{7}$ & $4,13.10^{4}$ & + & + \\
\hline & 4 & $2,67.10^{7}$ & $>6,5 \cdot 10^{5}$ & + & + \\
\hline \multirow[t]{4}{*}{ Sentul } & 1 & $>6,5 \cdot 10^{6}$ & $>6,5 \cdot 10^{6}$ & + & - \\
\hline & 2 & $>6,5 \cdot 10^{6}$ & $6,32 \cdot 10^{4}$ & + & - \\
\hline & 3 & $7,29.10^{5}$ & $4,39 \cdot 10^{4}$ & - & - \\
\hline & 4 & $5,18.10^{6}$ & $2,96.10^{6}$ & + & + \\
\hline
\end{tabular}

Keterangan: $\mathrm{CFU}=$ Colony Forming Unit, V . parahaemolyticus + menunjukkan adanya koloni ungu dan biru kehijauan pada media uji yang digunakan, Salmonella + menunjukkan adanya koloni berwarna merah muda pada media uji yang digunakan

Menurut SNI (1992) syarat mutu mikrobiologis ikan pindang adalah TPC $1.10^{5}$ per gram, E. coli maksimal 3 per gram, sedangkan Salmonella dan Vibrio harus negatif. Secara umum ada empat faktor utama yang mempengaruhi daya awet ikan pindang yaitu bahan baku ikan, cara atau metode pemindangan, metode pengemasan ikan pindang serta perilaku personil yang terlibat dalam proses pemindangan maupun penyimpanan

Bahan baku dan bahan pembantu (khususnya garam dan air) yang digunakan untuk pengolahan tradisional harus mempunyai mutu dan kesegaran tinggi. Para pengolah sering berpendapat bahwa bahan baku dan bahan pembantu untuk pengolahan tradisional tidak harus bermutu tinggi. Hal tersebut dikarenakan pihak pengolah tidak berorientasi pada produk akhir. Berdasarkan pendapat tersebut maka kebanyakan pengolah ikan dengan sengaja menunda pembelian ikan basah di pelelangan hingga siang hari, yakni saat harga ikan sudah jauh menurun dibandingkan dengan waktu baru diturunkan dari dari kapal, meskipun mutunya sudah jauh menurun
(Heruwati, 2002). Hal tersebut dimungkinkan karena akan memperoleh insentif lebih tinggi karena modal yang dikeluarkan untuk membeli bahan baku lebih sedikit. Hal lain yang harus diperhatikan berkaitan dengan bahan baku ikan yang akan diolah menjadi pindang, yaitu asal perairan tempat ikan tersebut ditangkap oleh nelayan. Ikan yang berasal dari perairan yang tercemar mempunyai kualitas mikrobiologis dan kemis yang lebih rendah dari pada ikan yang berasal dari perairan yang kurang tercemar. Pada penelitian ini asal ikan pindang bervariasi mulai dari Bantul, Rembang, Purworejo, Cilacap dan Prigi (Jawa Timur) (Tabel 2).

Berdasarkan wawancara dengan pedagang, ikan pindang yang tidak habis terjual akan dijual lagi keesokan harinya. Untuk mencegah supaya tidak cepat busuk, ikan-ikan tersebut akan direbus atau dikukus kembali. Hal tersebut dapat diketahui dari penampakan fisik ikan tongkol yang menjadi keras. Hal ini sesuai dengan pendapat Heruwati (2002), perebusan berulang-ulang atau sterilisasi membuat tekstur ikan menjadi keras. 
Tabel 2. Karakteristik pindang tongkol yang berasal dari beberapa pasar di Yogyakarta

\begin{tabular}{|c|c|c|c|c|c|c|}
\hline Pasar & Pedagang & $\begin{array}{c}\text { Asal } \\
\text { Pindang }\end{array}$ & $\begin{array}{c}\text { Lokasi dan Kondisi } \\
\text { sekitar tempat berjualan }\end{array}$ & $\begin{array}{l}\text { Umur } \\
\text { simpan }\end{array}$ & $\begin{array}{l}\text { kriteria pindang } \\
\text { yang dijual }\end{array}$ & $\begin{array}{l}\text { sisa dagangan } \\
\text { laku per hari }\end{array}$ \\
\hline \multirow[t]{4}{*}{ Beringharjo } & 1 & Rembang & $\begin{array}{l}\text { Di luar pasar, dekat dengan } \\
\text { penjual daging ayam maupun } \\
\text { pembuangan sampah, } \\
\text { pindang saling ditumpuk dan } \\
\text { tidak ditutup. }\end{array}$ & $\begin{array}{l}2 \text { hari s/d } \\
1 \text { minggu }\end{array}$ & $\begin{array}{l}\text { Basah, tekstur } \\
\text { keras, mata } \\
\text { jernih, dan warna } \\
\text { sisik cerah }\end{array}$ & $5 \mathrm{~kg}$ \\
\hline & 2 & Rembang & $\begin{array}{l}\text { Di luar pasar, dekat dengan } \\
\text { penjual daging ayam dan } \\
\text { parkiran pinggir jalan, } \\
\text { pindang saling ditumpuk dan } \\
\text { tidak ditutup. }\end{array}$ & $\begin{array}{l}3 \text { hari s/d } \\
1 \mathrm{minggu}\end{array}$ & $\begin{array}{l}\text { Basah, tekstur } \\
\text { keras, mata } \\
\text { keruh, dan warna } \\
\text { sisik kusam }\end{array}$ & $5 \mathrm{~kg}$ \\
\hline & 3 & Purworejo & $\begin{array}{l}\text { Di luar pasar, dekat dengan } \\
\text { penjual daging ayam dan } \\
\text { parkiran pinggir jalan, } \\
\text { pindang saling ditumpuk dan } \\
\text { tidak ditutup. }\end{array}$ & $\begin{array}{l}2 \text { hari s/d } \\
1 \text { minggu }\end{array}$ & $\begin{array}{l}\text { Basah, tekstur } \\
\text { keras, mata } \\
\text { jernih, dan warna } \\
\text { sisik kusam }\end{array}$ & $4 \mathrm{~kg}$ \\
\hline & 4 & Purworejo & $\begin{array}{l}\text { Di luar pasar, dekat dengan } \\
\text { penjual daging ayam dan } \\
\text { parkiran pinggir jalan, } \\
\text { pindang saling ditumpuk dan } \\
\text { tidak ditutup. }\end{array}$ & $\begin{array}{l}2 \text { hari s/d } \\
1 \text { minggu }\end{array}$ & $\begin{array}{l}\text { Basah, tekstur } \\
\text { keras, mata } \\
\text { keruh, dan warna } \\
\text { sisik cerah }\end{array}$ & $3 \mathrm{~kg}$ \\
\hline \multirow[t]{4}{*}{$\begin{array}{l}\text { Condong } \\
\text { Catur }\end{array}$} & 1 & Bantul & $\begin{array}{l}\text { Di luar pasar, dekat dengan } \\
\text { penjual daging ayam dan } \\
\text { pembuangan sampah, } \\
\text { pindang saling ditumpuk dan } \\
\text { tidak ditutup. }\end{array}$ & $\begin{array}{l}2 \text { hari s/d } \\
1 \text { minggu }\end{array}$ & $\begin{array}{l}\text { Kering, tekstur } \\
\text { Keras, mata } \\
\text { keruh, dan warna } \\
\text { sisik kusam }\end{array}$ & $3 \mathrm{~kg}$ \\
\hline & 2 & Rembang & $\begin{array}{l}\text { Di luar pasar, dekat dengan } \\
\text { penjual daging ayam dan } \\
\text { parkiran pinggir jalan, } \\
\text { pindang saling ditumpuk dan } \\
\text { tidak ditutup. }\end{array}$ & $\begin{array}{l}3 \text { hari s/d } \\
1 \text { minggu }\end{array}$ & $\begin{array}{l}\text { Basah, tekstur } \\
\text { keras, mata } \\
\text { keruh, dan warna } \\
\text { sisik kusam }\end{array}$ & $4 \mathrm{~kg}$ \\
\hline & 3 & Rembang & $\begin{array}{l}\text { Di luar pasar, dekat dengan } \\
\text { penjual daging ayam dan } \\
\text { parkiran pinggir jalan, } \\
\text { pindang saling ditumpuk dan } \\
\text { tidak ditutup. }\end{array}$ & $\begin{array}{l}2 \text { hari s/d } \\
1 \text { minggu }\end{array}$ & $\begin{array}{l}\text { Basah, tekstur } \\
\text { keras, mata } \\
\text { keruh, dan warna } \\
\text { sisik kusam }\end{array}$ & $4 \mathrm{~kg}$ \\
\hline & 4 & Rembang & $\begin{array}{l}\text { Di luar pasar, dekat dengan } \\
\text { penjual daging ayam dan } \\
\text { parkiran pinggir jalan, } \\
\text { pindang saling ditumpuk dan } \\
\text { tidak ditutup. }\end{array}$ & $\begin{array}{l}2 \text { hari s/d } \\
1 \text { minggu }\end{array}$ & $\begin{array}{l}\text { Basah, tekstur } \\
\text { keras, mata } \\
\text { keruh, dan warna } \\
\text { sisik kusam }\end{array}$ & $4 \mathrm{~kg}$ \\
\hline \multirow[t]{4}{*}{ Demangan } & 1 & Rembang & $\begin{array}{c}\text { Di dalam pasar, dekat } \\
\text { pedagang pisau dan makanan } \\
\text { kecil, pindang saling } \\
\text { ditumpuk dan tidak ditutup. }\end{array}$ & 2 hari & $\begin{array}{l}\text { Basah, tekstur } \\
\text { lunak, mata } \\
\text { jernih, warna } \\
\text { sisik cerah }\end{array}$ & t.t \\
\hline & 2 & $\begin{array}{l}\text { Rembang, } \\
\text { Juana }\end{array}$ & $\begin{array}{c}\text { Di dalam pasar, dekat } \\
\text { dengan pedagang buah, sayur } \\
\text { dan telur rebus, pindang } \\
\text { saling ditumpuk dan tidak } \\
\text { ditutup. }\end{array}$ & 2 hari & $\begin{array}{l}\text { Basah, tekstur } \\
\text { lunak, mata } \\
\text { jernih, warna } \\
\text { sisik cerah }\end{array}$ & t.t \\
\hline & 3 & $\begin{array}{l}\text { Prigi, } \\
\text { Jawa } \\
\text { Timur }\end{array}$ & $\begin{array}{l}\text { Di dalam pasar, dekat dengan } \\
\text { pedagang sayur, tahu, sosis, } \\
\text { dan ikan, pindang saling } \\
\text { ditumpuk dan tidak ditutup. }\end{array}$ & 2 hari & $\begin{array}{l}\text { Basah, tekstur } \\
\text { lunak, mata } \\
\text { jernih, warna } \\
\text { sisik cerah }\end{array}$ & t.t \\
\hline & 4 & Rembang & $\begin{array}{l}\text { Di luar pasar, dekat dengan } \\
\text { pedagang ayam, sayur dan } \\
\text { ikan dipinggir jalan, pindang } \\
\text { saling ditumpuk dan tidak } \\
\text { ditutup. }\end{array}$ & 2 hari & $\begin{array}{l}\text { Basah, tekstur } \\
\text { lunak, mata } \\
\text { jernih, warna } \\
\text { sisik cerah }\end{array}$ & t.t \\
\hline
\end{tabular}




\begin{tabular}{|c|c|c|c|c|c|c|}
\hline Pasar & Pedagang & $\begin{array}{c}\text { Asal } \\
\text { Pindang }\end{array}$ & $\begin{array}{c}\text { Lokasi dan Kondisi } \\
\text { sekitar tempat berjualan }\end{array}$ & $\begin{array}{l}\text { Umur } \\
\text { simpan }\end{array}$ & $\begin{array}{l}\text { kriteria pindang } \\
\text { yang dijual }\end{array}$ & $\begin{array}{l}\text { Sisa dagangan } \\
\text { laku per hari }\end{array}$ \\
\hline \multirow[t]{4}{*}{ Kranggan } & 1 & Rembang & $\begin{array}{c}\text { Di dalam pasar, dekat } \\
\text { dengan pedagang ayam, } \\
\text { sayur dan ikan, pindang } \\
\text { saling ditumpuk dan tidak } \\
\text { ditutup. }\end{array}$ & 2 hari & $\begin{array}{l}\text { Basah, tekstur } \\
\text { lunak, mata } \\
\text { jernih, warna } \\
\text { sisik cerah }\end{array}$ & t.t \\
\hline & 2 & Rembang & $\begin{array}{c}\text { Di dalam pasar, dekat } \\
\text { dengan pdagang ayam, } \\
\text { sayur, bumbu, pindang } \\
\text { saling ditumpuk dan tidak } \\
\text { ditutup. }\end{array}$ & 2 hari & $\begin{array}{l}\text { Basah, tekstur } \\
\text { lunak, mata } \\
\text { jernih, warna } \\
\text { sisik cerah }\end{array}$ & t.t \\
\hline & 3 & Rembang & $\begin{array}{c}\text { Di dalam pasar, dekat } \\
\text { dengan pedagang sayur, } \\
\text { kelapa, bumbu, pindang } \\
\text { saling ditumpuk dan tidak } \\
\text { ditutup. }\end{array}$ & 2 hari & $\begin{array}{l}\text { Basah, tekstur } \\
\text { lunak, mata } \\
\text { jernih, warna } \\
\text { sisik cerah }\end{array}$ & t.t \\
\hline & 4 & Rembang & $\begin{array}{c}\text { Di dalam pasar, dekat } \\
\text { dengan pedagang beras } \\
\text { bumbu, mainan dan baju, } \\
\text { pindang saling ditumpuk } \\
\text { dan tidak ditutup. }\end{array}$ & 2 hari & $\begin{array}{l}\text { Basah, tekstur } \\
\text { lunak, mata } \\
\text { jernih, warna } \\
\text { sisik cerah }\end{array}$ & t.t \\
\hline \multirow[t]{4}{*}{ Sentul } & 1 & Rembang & $\begin{array}{l}\text { Di luar pasar, dekat dengan } \\
\text { penjual daging ayam dan } \\
\text { pembuangan sampah, } \\
\text { pindang saling ditumpuk } \\
\text { dan tidak ditutup. }\end{array}$ & 2 hari & $\begin{array}{l}\text { Basah, tekstur } \\
\text { keras, mata } \\
\text { jernih, dan warna } \\
\text { sisik cerah }\end{array}$ & habis \\
\hline & 2 & Rembang & $\begin{array}{l}\text { Di luar pasar, dekat dengan } \\
\text { penjual daging ayam dan } \\
\text { parkiran pinggir jalan, } \\
\text { pindang ditumpuk dan tidak } \\
\text { ditutup. }\end{array}$ & 3 hari & $\begin{array}{l}\text { Basah, tekstur } \\
\text { keras, mata } \\
\text { keruh, dan warna } \\
\text { sisik kusam }\end{array}$ & habis \\
\hline & 3 & Purworejo & $\begin{array}{l}\text { Di luar pasar, dekat dengan } \\
\text { penjual daging ayam dan } \\
\text { parkiran pinggir jalan, } \\
\text { pindang saling ditumpuk } \\
\text { dan tidak ditutup. }\end{array}$ & $\begin{array}{l}2 \text { hari s/d } \\
1 \text { minggu }\end{array}$ & $\begin{array}{c}\text { Basah, tekstur } \\
\text { keras, mata cerah } \\
\text { dan warna sisik } \\
\text { gelap }\end{array}$ & t.t \\
\hline & 4 & Cilacap & $\begin{array}{l}\text { Di luar pasar, dekat dengan } \\
\text { penjual daging ayam dan } \\
\text { parkiran pinggir jalan, } \\
\text { pindang saling ditumpuk } \\
\text { dan tidak ditutup. }\end{array}$ & $\begin{array}{l}2 \text { hari s/d } \\
1 \text { minggu }\end{array}$ & $\begin{array}{l}\text { Basah, tekstur } \\
\text { keras, mata } \\
\text { keruh, dan warna } \\
\text { sisik cerah }\end{array}$ & $3 \mathrm{~kg}$ \\
\hline
\end{tabular}

Keterangan: t.t $=$ tidak teridentifikasi

Jumlah bakteri coliform yang ditemukan pada semua sampel masih tinggi. Hal tersebut dapat disebabkan karena menggunakan sembarang air yang tersedia walaupun air tersebut kotor karena umumnya air bersih sulit didapatkan di lokasi pengolahan ikan. Jumlah total coliform yang tinggi $\left(2,96->6,5 \times 10^{6}\right.$ $\mathrm{CFU} / \mathrm{g}$ ) dijumpai pada ikan pindang yang dijual oleh pedagang 3 dan 4 dari pasar Beringharjo serta pedagang 1 dan 4 dari pasar Sentul. Menurut Sikorski et al. (1998), Enterobacteriaceae sering ditemukan pada ikan olahan yang berkadar air tinggi juga

Salmonella typhimurium dan Vibrio parahaemolyticus.

Ditemukannya bakteri yang diduga $V$. parahaemolyticus pada sebagian besar pindang tongkol yang berasal dari beberapa pasar di Yogyakarta dapat disebabkan proses pemindangan belum mematikan semua $V$. parahaemolyticus yang ada atau dapat juga disebabkan karena kontaminasi silang, misalnya wadah yang digunakan, kontaminasi dari proses transport, atau lingkungan di sekeliling dimana ikan pindang tersebut ditempatkan. Berdasarkan dari Tabel 2 juga diketahui bahwa beberapa pedagang ikan 
pindang berjualan di dekat pedagang ikan segar.

Pada proses pemindangan, garam yang diberikan sebanyak 6\%, sedangkan $V$. parahaemolyticus merupakan bakteri yang tahan pada kadar garam sampai 8\%. Uji lanjutan dilakukan dengan menumbuhkan isolat yang diduga $V$. parahaemolyticus pada media Nutrien Cair yang mengandung kadar garam $0-10 \%$. Dari 8 isolat $V$. parahaemolyticus yang diuji, diduga 5 isolat merupakan positif $V$. parahaemolyticus karena masih dapat hidup pada media Nutrien Cair dengan kadar garam 7, $5 \%$ (Tabel 3).

Tabel 3. Hasil Uji Lanjutan Vibrio parahaemolyticus Pada Media Nutrien Cair dengan Penambahan Variasi Konsentrasi $\mathrm{NaCl}$

\begin{tabular}{|c|c|c|c|c|c|c|}
\hline \multicolumn{2}{|c|}{ Asal sampel } & \multicolumn{5}{|c|}{ Nutrien Cair+ NaCl } \\
\hline Pasar & Pedagang & $0 \%$ & $2.5 \%$ & $5.0 \%$ & $7.5 \%$ & $10.0 \%$ \\
\hline \multirow{2}{*}{ Beringharjo } & 1 & + & + & + & + & - \\
\hline & 4 & + & + & + & + & - \\
\hline \multirow[t]{2}{*}{ Condongcatur } & 1 & + & + & + & + & - \\
\hline & 4 & + & + & + & + & - \\
\hline Demangan & 4 & + & + & + & + & - \\
\hline \multirow[t]{2}{*}{ Kranggan } & 2 & + & + & + & - & - \\
\hline & 4 & + & + & + & - & - \\
\hline Sentul & 4 & + & + & + & - & - \\
\hline
\end{tabular}

Keterangan : Tanda + menunjukkan adanya pertumbuhan V. parahaemolyticus, ditandai dengan keruhnya media dan ada endapan putih dibagian bawah media.

Tanda - menunjukkan tidak adanya pertumbuhan $V$. parahaemolyticus, ditandai dengan tidak adanya endapan dan warna media tidak keruh.

Ditemukannya bakteri yang diduga Salmonella pada banyak sampel mungkin disebabkan karena pindang ikan dijual berdekatan dengan pedagang ayam, daging ataupun sayur-sayuran. Dari 8 isolat yang diduga Salmonella dilanjutkan uji pendugaan dengan media TSI dan LIA, sebanyak 5 isolat menunjukkan hasil positif. Hal tersebut ditunjukkan dengan terbentuknya warna ungu gelap pada media LIA dan pada media TSI ditandai dengan warna merah dan muncul warna hitam sebagai produksi $\mathrm{H}_{2} \mathrm{~S}$ (Tabel 4).

Tabel 4. Hasil Uji Lanjutan Salmonella Pada Media TSI dan LIA

\begin{tabular}{cccccc}
\hline \hline \multicolumn{2}{c}{ Asal sampel } & \multicolumn{2}{c}{ Media LIA } & \multicolumn{2}{c}{ Media TSI } \\
\hline Pasar & Pedagang & Tegak & Miring & Tegak & Miring \\
\hline Beringharjo & 1 & - & - & - & - \\
Condongcatur & 4 & + & + & + & + \\
Demangan & 1 & + & + & + & + \\
Kranggan & 4 & + & + & + & + \\
Sentul & 4 & - & - & - & - \\
\end{tabular}

Keterangan :

Hasil + pada Media TSI ditandai dengan warna merah dan muncul warna hitam sebagai produksi $\mathrm{H}_{2} \mathrm{~S}$

Hasil + pada media LIA ditandai dengan warna ungu gelap (purple)

Hasil - pada media TSI ditandai dengan terbentuknya warna kuning pada media.

Hasil - pada media LIA ditandai dengan berubahnya media dari warna ungu keruh menjadi kuning.

Menurut Priyono dan Raharjo (2003), upaya menjaga keamananan pada ikan pindang sebenarnya harus dimulai dari tingkat produsen. Kemudian di tingkat pedagang sebagai rantai distribusi utama yang memegang peranan penting dalam menjaga produk ikan pindang tetap aman selama distribusi berlangsung dan di tingkat pembeli yang 
berperan penting dalam upaya terakhir meminimalisasi bahaya yang menyertai ikan pindang.

Rekomendasi yang dapat diberikan setelah penelitian ini adalah: pemilihan ikan tongkol diusahakan mempunyai ciri morfologi dan organoleptik yang baik, misal ikan mempunyai bagian tubuh yang utuh tidak cacat/koyak, tekstur yang kenyal, warna sisik cerah, warna insang merah segar, bau segar, dan mata jernih, pembersihan dan pencucian ikan tongkol menggunakan air bersih, pengukusan ikan dilakukan pada kondisi bersih dengan suhu $100^{\circ} \mathrm{C}$ selama 2 jam, kranjang yang digunakan tidak menggunakan kranjang bekas, pindang diusahakan dalam kondisi tertutup pada saat pendistribusian, penjualan pindang kranjangan hendaknya diusahakan tertutup dan di tempat yang jauh dari penjualan daging dan ikan mentah.

\section{Kesimpulan}

Mutu bakteriologis beberapa pindang tongkol kranjangan yang berasal dari beberapa pasar di Yogyakarta belum memenuhi persyaratan yang ditetapkan oleh SNI 01-27171992. Kandungan total mikrobia berkisar antara $2,4 \times 10^{5}-5,27 \times 10^{7} \mathrm{CFU} / \mathrm{g}$, bakteri coliform antara $<2,5 \times 10^{1}->6,5 \times 10^{6} \mathrm{CFU} / \mathrm{g}$. Dari 20 sampel yang dianalisa, 60\% sampel diduga positif $V$. parahaemolyticus dan $50 \%$ sampel diduga positif terkontaminasi Salmonella.

Kondisi sekitar penjual ikan pindang mempengaruhi mutu bakteriologis pindang tongkol kranjangan.

\section{Ucapan Terima Kasih}

Penulis mengucapkan terima kasih kepada Febrianto dan Antonia Wahyu Tri Yuniarti selaku asisten peneliti yang telah membantu dalam penelitian. Terima kasih juga diucapkan kepada Kelompok Pemerhati Keamanan Mikrobiologis Produk Pangan, PSPG-UGM dan Fakultas Biologi UAJY yang telah membantu fasilitas sehingga penelitian ini dapat terlaksana.

\section{Daftar Pustaka}

Anonim. 2004. Kejadian Keracunan di Kabupaten Sleman. Dinas Kesehatan Kabupaten Sleman, Yogyakarta.

Fardiaz, S. 1989. Analisis Mikrobiologi Pangan. PAU Pangan dan Gizi Institut Pertanian Bogor, Bogor.

Hadiwiyoto, S. 1997. Hasil Perikanan: Manfaat dan Keamanan serta Implikasinya pada Kesehatan: Tinjauan dari Sisi Teknologi Pengolahan dan Lingkungannya. Agritech 17(3): 28-43.

Heruwati, E.S. 2002. Pengolahan ikan secara tradisional: Prospek dan peluang pengembangan. Jurnal Litbang pertanian. 21(3): 92-99.

Moeljanto, 1994. Pengawetan dan Pengolahan Hasil Perikanan. Penebar Swadaya. Jakarta.

Peranginangin, R. 1995. Kandungan Nilai Gizi Produk Perikanan Olahan Tradisional. Prosiding Widyakarya Nasional: Khasiat Makanan Tradisional. Kantor Kementrian Negara Urusan Pangan Republik Indonesia.

Priyono, P.R. dan Raharjo, S. 2003. Tingkat Pengetahuan, Sikap, dan Praktek Keamanan Pangan Pedagang dan Kebiasaan Pembeli Ikan Pindang Keranjang di Kota Yogyakarta. Agrosains 16(3): 307-324.

Rahayu, E.S. 2003. Uji Mikrobiologi Bahan Pangan. Fakultas Teknologi Pertanian Universitas Gajah Mada, Yogyakarta.

Saleh, M. dan Heruwati, E.S. 1995. Ikan Pindang, Penyumbang Gizi yang Handal Bagi Masyarakat. Prosiding Widyakarya Nasional: Khasiat Makanan Tradisional. Kantor Kementrian Negara Urusan Pangan Republik Indonesia.

Sikorski, Z., Haard, N., Motohiro, T. and Pan, B.S. 1998. Quality In: Burt, J.R. 1998. Fish Smoking and Drying, the Effect on the Nutrion Properties of Fish. Elsevier Applied Science, London.

Suliantari, Koswara, S. dan Danur, I.A.I. 1994. Mempelajari Metode Reduksi Kadar Histamin dalam Pembuatan Ikan Pindang Tongkol (Euthynnus affinis). Bul. Tek. dan Industri Pangan V(3):44-49.

Standar Nasional Indonesia. 1992. Syarat Mutu Ikan Pindang. 